\title{
Leadership in Academic Libraries
}

By WILLIAM S. DIX

$\mathrm{T}^{\mathrm{s}}$ HE TOPIC PROPOSED for discussion is both important and interesting. It faces issues of more concern to our profession, I venture to say, than automation, for example, the subject of a discussion over which I presided here several years ago. For leadership clearly deals with people, and people must be the prime concern in any enterprise of moment. This era in Western civilization may be inclined to forget this principle from time to time, but our profession is certainly one with a special responsibility to insist upon humanistic values, for ourselves and for others. You will permit me then, I trust, to speak in quite personal terms, to try to respond to our question in terms of my own experience.

In order to start the discussion, you will permit me, I hope, a neat bit of circular argument: to ask who the leaders are, what the duties of their positions are, what preparation is desirable for the performance of those duties, and finally where this preparation may be obtained. This formulation of the question begs any number of questions, such as, "Are the leaders really leading?", but it at least gets us moving. Perhaps we can break out of the circle later.

Let us assume that leadership rests with those assigned the responsibility of leading in our academic libraries, large and small: the chief librarians and their immediate staff associates. One hopes that original thinking and new ideas emerge from all staff levels, but since the implementation of these ideas tends to rest with the titular heads of these staffs, we should probably limit our definition to the senior staff members. It is my impression that better decisions result when they are made collectively
Dr. Dix is Librarian, Princeton University. This paper was given at the Eastern College Librarians' Conference, Columbia University, November 28, 1959.

rather than individually and when there is thorough discussion with many members of the staff before the decision is made; but the decision and presumably the leadership rest with the senior group. It may be that my assignment was to speak of the chief librarian only, and in a sense I shall speak of him primarily, but it is out of this group that chief librarians come, and aside from some unavoidable specialization nearly all should be, I believe, on their way to senior posts and thus all should share in the experiences and duties I shall try to outline.

What does the representative member of this leadership group do? How does he spend his days and nights? Just what are his activities and responsibilities?

First of all, he is by definition an officer-and a responsible officer-of an educational institution. His objectives are identical with those of the teaching faculty in this respect, and the more completely he can understand and participate in regular faculty activities, the more successful he will be. Some departmental affiliation and some classroom teaching help immeasurably here, but they are not essential. The important thing seems to me to be that the teaching faculty accept him spontaneously as one of themselves, working in a common cause, and not as a hostile member of something over there called The Administration. Happy is that college in which the two groups are essentially one! 
At the same time, he is a senior member of the college administration, usually reporting to the president and certainly owing his full loyalty to and support of the administrative decisions of his superior officer.

In this educational role the librarian spends a great deal of time talking with classroom teachers, learning how the library can function not merely as a service organization but as an integrated part of the curriculum. He must sit with faculty and trustee committees on educational policy, perhaps making direct contributions, certainly making sure that the library is prepared to play its part in each new educational development. He must by a variety of devices maintain contact with the students of his institution, making sure that they find the library an inviting and exciting place, not merely a warehouse of books hedged about with a forbidding network of rules. His is perhaps the post on the campus most clearly dedicated to getting students to read widely and deeply, and every ounce of his energy and ingenuity can be spent on this task alone.

In the larger institutions the role of the library in providing its share of the vast pool of research material on which American scholarship depends and in conserving the manuscript and printed record of civilization is clear. A major activity of the librarian then must be the assembling and the preparing for use of the materials of scholarship. He must know what these materials are, he must devise ways of acquiring them, and he must arrange them so that the scholar can lay hands on the item he needs, even though he may have no previous knowledge of its existence.

This short sentence obviously contains a whole world of librarianship, really beyond the grasp of any one person. What one of us can know what comprises a complete set of the Mongolian Kanjur, can wheedle a family file of plantation records from an elderly lady, or $\$ 500,000$ from a state legislature, and can read and catalog an Arabic manuscript of the tenth century? It is too much to expect any one person to be able to perform these three and the other hundreds of essential library acts. Yet leadership at the management level, which is I take it what we are talking about, requires that one person make responsible decisions on all of them.

Having thus glanced briefly at the two principal and overlapping roles of the academic librarian, the direct educational role and the collection building and organizing role, I should like to return to the question of how he spends his time, what he really does, always keeping in mind these twin purposes of the whole operation.

In the first place, alas, comes money. Libraries require money, and in constantly increasing quantities. Without it, nothing is possible, and it is the responsibility of the academic librarian in a position of leadership in an individual library to get it from somewhere. Money for salaries, for acquisitions, for endowment, for buildings and improvements, for dozens of miscellaneous activities and programs must be obtained from the college administration, from the legislature, from federal research contracts, from the foundations, from alumni, from any source that is not downright illegal. Included are the steady and endless attempts to convince those who have the money of the importance of libraries and of yours in particular, the marshalling of impressive arrays of statistics and documents to show needs, which always seem a little less impressive to those who have the money, the little luncheons and dinners carefully contrived to present the library in precisely the right light, and the speeches. All of this takes time - time which you, your wife, and your staff all begrudge. You would like to handle some books and have an evening with your family, your wife thinks you are ruining your health, and your staff 
thinks you are off in the fleshpots of New York instead of running your library or your department. Put this time down at 20 per cent of the librarian's total. There is no short cut and no easy formula. The only rule I have learned is, "Never ask for anything which you don't sincerely believe is important." The librarian who tries to get all he can out of his college financial officer, regardless of need, is not exercising leadership, nor will he continue to get real support for the library.

There is no substitute for moneyexcept books. A steady flow of gifts of important books and manuscripts solves a few of the problems which money eases. The processes by which this flow is maintained need no explanation. I can let an eminent and scholarly New York collector, C. Waller Barrett, describe the situation as he did at the ACRL, Rare Books Section meeting last summer in Washington:

... An engaging aspect of this discernible trend is the metamorphosis in the librarian-collector-benefactor relationship. No longer does the librarian or curator sit quietly in his ivory tower waiting for collections or parts of collections to come his way by gift or bequest. He realizes that the competition has become too keen. $\mathrm{He}$ must come out of the cloister and do battle with the leaders of other libraries or his own institution will lose ground in the race. Too often has he found scrawled on the wall the words "Jim Babb was here." Too often has he opened negotiations for a desirable library only to learn that the material is already being packed by a bustling and peripatetic gentleman from California with "A Passion for Books." Moreover, his seismograph has recorded the tremors caused by the earth-shaking tread of a Behemoth educational empire in the Southwest as it engulfs vast libraries in its voracious maw. He has likewise experienced that gone feeling which results from watching choice collections and stellar rarities fall into the grasp of an opulent and aggressive university in the Middle West. No, for better or worse, the scholarly, withdrawn functionary, immersed in the administrative detail of providing books for his readers, is giving way to the energetic, gregarious individual of large acquaintanceship who spreads his nets far and wide for supporters and backers. The former pedestrian acquisition policies are being replaced by an unremitting and aggressive campaign for material of worth and publicity value. Where formerly fund-raising was left to the president and the board of trustees, the librarian today has his own show, his own organization of library friends or associates, his house organ and his selected list of devoted alumni or other benefactors good for occasional or regular gifts of large amounts. The sky is the limit and the new wing or the whole new library building not too much to hope for.

Put down another 20 per cent of the librarian's time for these activities.

Then he must spend a considerable amount of time with the staff, more with his chief aides, less with individual staff members of lesser rank. He will, I trust, not fall into that tempting trap of trying to do everything himself but will devote his time to guiding and stimulating the staff in developing attitudes and procedures which will keep the daily internal mechanism of the library running smoothly. He will gather around him good people, then give them their heads. But he must make his own force felt everywhere, especially in the basic hiring and firing mechanism by which the library organism, like the human organism, constantly renews itself. He must make sure that library work is not the mechanical repetition of processes of circulation, of cataloging, of whatever you will that once had meaning but no longer has any relevance to the central roles of the academic library. Here there is one more opportunity for real leadership, for devising the perfect balance between means and ends.

Put down at least 30 per cent of our librarian's time for the internal operation of the library. 
Then the librarian has a special concern for the academic library's publicor publics-the groups whom he must somehow keep happy; not always an easy task even when there is enough money, when the gifts are flowing in, when the internal machinery is humming. There are, as you all know, a surprising number of groups with whom relations must be kept smooth: the undergraduates, the graduate students, the faculty, the administration, the trustees, the alumni, the Friends of the Library, often the non-university users of the library, the visitors both foreign and domestic. In all of these groups there are many people who insist upon dealing with the senior librarians and who must have their grievances amended. Better yet, they must be prevented from developing grievances by being kept informed, by having their needs properly satisfied. This requires committees and meetings, speeches and articles, conferences and interviews-public relations in the real sense, not advertising but service and communication.

Put down at least 20 per cent for this.

Put down another 10 per cent for miscellaneous activities. Every librarian, it is said, builds a new building at least once in his career and in the larger institutions he is constantly faced with architectural problems. He must be at least an amateur architect. He must carry his share of the non-library faculty load-the President's Committee to Solve the Parking Problem (which never does), the chairmanship of the Faculty Club (which always faces a financial crisis), the Freshman Parents' Day speech, etc., etc.

Our librarian has now used up 100 per cent of his day (and I do not mean a 9to-5 day) in the affairs of his own library and his own university. Is he yet exercising library leadership, even though he performs all of these varied activities to perfection? I doubt it.

The leadership about which I think we are talking is more than local. There must be leadership at the national and international levels. It becomes increasingly clear that many of the problems of libraries can be solved only by cooperation and collaboration. We must concern ourselves with such things as the development of an international cataloging code; new technological advances with potential library applications; the development of libraries and bibliographic tools in other parts of the world. We must engage in research and publication; even though we can expect more research to be carried on in the library schools, the practicing librarian, like the practicing medical man, must continue to inquire and report to the profession the results of these investigations. We must participate in and guide the activities of our professional organizations and of related scholarly and bibliographic societies.

In other words, it is essential that we be leaders in enterprises of this sort as well as in the management of individual libraries.

Finally, in this hasty review of what the librarian actually does, I must not neglect participation as a citizen in matters which have no direct relation to librarianship. If we are to increase the respect in which our profession is held, librarians must take part prominently in the activities of the hundreds of nongovernmental organizations which are so characteristic a feature of American society, from the PTA and the Community Fund, at the local level, on up. The stock image of the librarian as a timid, ineffectual old lady will continue to haunt us until we demonstrate our ability to participate forcefully in public affairs.

Don't ask me where the librarian can find time for these activities which I have sketched out as those of the library leader! We have ruthlessly assigned 100 per cent of his working day; his evenings and week ends are not sufficient for his outside professional and civic activities, 
and he must still find time to read, to think, and to go fishing if he is to remain sane and useful. But there it is. These are the activities which leadership entails, these are the occupations of the library leader, as I see them.

You may not agree with this hasty over-simplification, this distribution of the librarian's time. There is a semantic difficulty in discussing a topic of this sort without giving offense or sounding superior. I am merely trying to identify the activities of a group occupying a position of leadership, not to make social, or economic, or intellectual distinctions. Once we have identified those activities, we can then ask what qualities are required to perform these duties and, after that, ask where one looks to find men possessing these qualities.

What then are the qualities that seem to be required for the exercise of library leadership of the sort I have attempted to outline? It was my original plan to list these qualities under each category of activities as I went along, but I soon ran out of abstract nouns describing the virtues. Thus, I shall try to list these qualities here.

First of all, if you accept my formulation of the two roles of the academic library, our librarian must have a deep conviction of the importance of education and an imaginative perception of the place of books and libraries in the educational process. He must be what is commonly called a "born teacher," with a joy in observing what happens to young men and women during four years of college.

To develop a research collection and make it serve scholarship he must be a scholar in some field, almost any field. I hasten to add that he need not be a very profound scholar, but he must have experienced the excitement of research himself in order to understand the scholar, who may be a very different sort of person from the teacher. He should possess the tools of scholarship, includ- ing languages, the more the better. $\mathrm{He}$ had better, I think, be a bookman and collector at heart; although some good teachers and scholars are not, I rather think that the librarian should be.

In combination then, the closer the librarian approaches the ideal of the teacher-scholar the better. But he must do this without giving up some other qualities which the teacher-scholar may lack and which our survey of his daily activities suggests as desirable.

To be able to lay his hands on money and to keep on doing it he must be responsible about money. He must be able to demonstrate to his college administration or to any other source of funds that he makes each dollar work as hard as it can. This canny thriftiness is often in direct opposition to the enthusiasm of the teacher-scholar-collector, but he must have both. (You can see that the picture already emerging here involves often a reconciliation of opposites; the word "balance" suggests itself here.) He must be able to persuade by talking, by writing, and by certain intangibles which I shall not even attempt to explain, but he must certainly be able, upon occasion, to use his native tongue subtly, eloquently, and forcefully. He must be a good committee man, must know instinctively that magic moment in discussion when a group can be swayed to his own point of view.

In his begging of books he must have empathy. He must be able to enjoy all kinds of collectors, both sane and insane.

For the internal management of the library he must of course have a thorough knowledge of library theory and procedures, from acquisitions to weeding. And he must know these operations in human terms, for they will be carried out by people under his direction. Thus, his task is primarily to introduce, to develop, to revise processes appropriate to the job to be done and which can be operated by the people actually available. The mechanisms themselves do not 
seem to be very complicated, but getting them to operate efficiently and economically in the hands of other people is terribly complicated. The qualities needed here are perhaps ingenuity, firmness, decision, and a great deal of human kindness and sympathy. Perhaps they are not very different from those required of a successful shop foreman, or football coach, or president of a shipping company-anyone who gets a job done through others. The kinds of basic knowledge required are vastly different, of course. The good librarian to make his systems work to serve education and scholarship must know a great deal about the alternative ways of getting things done in a library-call it library science-about the aims and devices of education itself, and about the methods of research. In addition he should know all he possibly can about the history and content of every book ever printed, hardly a project for a rainy Sunday.

In his dealings with his various publics, perhaps the qualities most serviceable are patience and tolerance, firmness and decision. It will also be useful if he has a fund of good stories (and I do not mean jokes) and if he knows enough not to use out-of-date undergraduate slang or the wrong fork or someone else's club tie.

For our 10 per cent miscellaneous category of library activities the qualifications are so diverse that it is useless to try to list them; you know as well as I that practically anything can happen in a library. May we simply say that the ideal librarian would fill out any room he has for more qualities with those of the lawyer, the architect, the psychiatrist, and any other half dozen professions you choose to name.

I have spent too much time already to attempt a list of the qualities needed by the librarian for his professional activities outside his own library or his activities as a citizen, although it may be that here lie the most important oppor- tunities for leadership for academic librarians. But I suspect that these qualities are not substantially different.

What can one say about this list of qualities and skills which we have been compiling? In the first place, it is a staggering list. Mr. Wilmarth Lewis compiled a similar list in 1960 when Yale was seeking a president:

Yale's next President must first of all be a Yale man and a great scholar-also a social philosopher who has at his finger tips a solution of all world problems, from Formosa to birth control.

He must be a good public relations man and an experienced fund-raiser.

He must be a magnificent speaker and a great writer.

He must be a man of the world and yet he must also have great spiritual qualities -a great administrator who can delegate authority.

He must be a leader-not too far to the right, not too far to the left, and of course not too much in the middle.

He must be a man of iron health and stamina, a young man-but also mature and full of wisdom.

He must be married to a paragon-a combination of Queen Victoria, Florence Nightingale, and the best-dressed woman of the year.

As I have been talking, you have, I don't doubt, realized that there is only One who has most of these qualifications. But there is a question even about Him: Is God a Yale Man?

We are not likely to find this paragon and shall have to stagger along without leadership if we have to wait for him. We shall have to put up with men and women who possess only some of these qualities. But we cannot do without many of them. For ours is a demanding profession. It can use just about as much as one can bring to it, and perfection is inconceivable, thank goodness.

I still remember something that was said to me nearly twenty years ago by an eminent brain surgeon, reputed then to be one of the three best in the world, a simple man of incredible skill who used 
to use his idle moments tying sutures for practice with thumb and forefinger inside a match box, a safety match box. We were riding along through the November night to a duck-shooting blind a hundred miles away and had fallen into one of those moods of intimacy that can grow in such circumstances. This great man turned to me, an awed instructor of English, and said, "I am just a plumber! I have certain skills and a certain body of knowledge, but I envy you men who deal with ideas and books, and human beings. You have the possibilities!"

Now I cannot accept his view of brain surgery, but I have come to think he was right about education and the teachers and librarians who work at the core of it. We have the possibilities, and as a consequence our list of requisites for optimum performance will be a staggering one.

Look at the list again and ask our final question: Where shall the academic library find its leadership? How can it be produced? One thing that is apparent is that a great many of the items on this list are fundamental personal attributes, desirable in any man or any profession, essential in many. (But, note, not all. A man may achieve greatness in some fields of science, and yet totally lack the ability to direct others, to work through a group. The bibliographer might become great with the same lack, but not the librarian.) These essential personal attributes can be cultivated but, I think, not created. If you would create them in a man, begin with his great-grandparents. The indestructibility, the reflexes, and the muscular coordination that make Joe Brown, or whoever it is, the leading ground gainer in professional football were nourished in some school, but they were not created there. To get our leaders we must start with good raw material, and this presents a problem, for the competition for this top-grade material among the professions is severe. It seems obvious that the de- mands which our evolving society makes are increasing so rapidly that we simply do not have enough people of fundamental native ability, we cannot educate them up out of the lower I.Q. ranks fast enough to fill the number of more demanding jobs which our society now requires. The library profession simply must compete harder for its share of leadership material.

Assuming that we can get our share of the material in some stage of development, what do we then do with it? Our list of qualities and skills seems to me to indicate that a really sound liberal education is the best preparation for them. You will note that I do not say a B.A. degree; a liberal education can be acquired in several ways, of which the easiest start is probably a good four-year college course. What about subject specialization? This, in my view, is related to the attaining of a feeling for teaching and a feeling for research, I cannot escape the impression that these two essential attributes can be attained best through actual practice. So, if a man is to teach or do research he must teach or do research in a subject. He must take at least the first steps toward knowing quite a lot about some one thing. The subject does not seem to me very important so long as it is something he can get his teeth into.

What about the essential library skills and knowledge? To be precise, what about the fifth-year library school degree? It seems to me highly desirable but not absolutely essential. Much of the actual material of the present master's degree curriculum can be learned in other ways: from experience, from the professional literature. But a year in a graduate library school is in my observation surely the obvious way to acquire the necessary specialized library knowl. edge, just as four years in an undergraduate college is the obvious way to get started on a liberal education.

The library school seems to be the 
best place also to get something else which may be more important. Attitudes seem to be high on my personal list of attributes for leadership. I have observed through the years that there is a most important library attitude-toward the role of libraries, toward the library's public, toward a number of things-and that this attitude comes naturally to the library school graduate and has to be learned with some difficulty by many (but not all) of those who enter the profession by other routes. This attitude may well be the most important product of library school education. I leave it to our colleagues in the schools to analyze the chemistry of its birth. It is closely related to the attitudes toward teaching and toward scholarship which I have stressed, and perhaps by a little tinkering with the molecules which make up the curriculum these attitudes too can be engendered in the library school.

I think that we are asking too much if we expect the library schools to create library leaders. There are too many factors involved; there are more years needed than the one year of library school. A Ph.D. won't make a leader, in library science or any other subject. Not all the great generals go to West Point.

There are some jobs, some activities, for which there probably can be no completely effective formal training. A college presidency is one. Where is the school for training college presidents? I suspect that an analysis of the way the great college president spends his time, of the qualities which make him effective, might produce a list not unlike the one we have just compiled. Where do you go to find a good college president? To the colleges, I hope, although I am told that good ones have come from other sources. Similarly, for library leaders one goes to the libraries, and in the production of these leaders the library school plays an important part, as the best place for learning both techniques and attitudes, as a center of research into library problems, and as the molder and conservator of the traditions which mark a true profession. But if an occasional academic librarian appears from some other source, even from outside the libraries, let us give thanks and welcome him with the magnificent friendliness and helpfulness with which I was welcomed a dozen years ago. We can use him.

Another problem which the library schools face, and which is of course a determining one for the product, is the quality of the people who seek admission. There are good people, to be sure, but not all of them are good, and there are not enough of them to fill all the positions of leadership after the normal attrition. It is not to the credit of any of us who run academic libraries that we fail year after year to make our own activities seem interesting and important enough to attract our own students into the profession. In self defense we might say that librarianship appeals to the more mature; that the undergraduate simply can't appreciate the joys and beauties of our occupation. It is undoubtedly true that some of our best recruits come in relatively late, and I am glad to see the schools adapting themselves to work-study schedules and other devices to facilitate this late entry.

Is it not, then, at this point that we recruit from the faculty? The problem is to make library careers attractive enough, in salary and in prestige, to invite faculty members at the instructor level to undertake library careers, learning the professional background in library school or elsewhere at this point. They would then presumably have had the exposure to teaching and research which, as I have indicated, seems to me desirable. I am of course not talking about the misfits and failures, although it is quite possible that a very promising librarian might not find classroom teaching congenial. I am talking about establishing ties between

(Continued on page 388) 
National Young Scientist. Young Scientists of America Foundation, Inc., P. O. Box 9007, Phoenix, Ariz. v. 1, no. 1, January 1960. Frequency not given. Price not given.

New Left Review. American Distributor: B. De Boer, 102 Beverley Road, Bloomfield, N. J. no. 1, January-February 1960. 6 issues per year. $\$ 4$.

New Orient. Artia, P. O. B. 790, Praha, Czechoslovakia. v. 1, no. 1, February 1960. Bimonthly. \$4.

Overview. Buttenheim Publishing Corporation, 470 Park Avenue South. New York 16. v. 1, no. 1, January 1960. Monthly. $\$ 5$.

Physics and Chemistry of Glasses. Society of Glass Technology, Thornton, Hallam Gate Road, Sheffield 10, England. v. 1, no. 1, February 1960. Bimonthly. $£^{6} 15$ s. per volume.

Pre-Views and Re-Views. Dorn and Kirschner Band Instrument Company, 77 Springfield Avenue, Newark 3, N. J. v. 1, no. 1, March 1960. Quarterly. Price not given.

Protective Packaging and Packaging Techniques. Boston Publishing Company, Inc., 221 Columbus Avenue, Boston. April 1960. Quarterly. Price not given.

Public Library Abstracts. Division of Library Science, Indiana University, Bloomington, Ind. v. 1, no. 1, January 1960. Quarterly. Price not given.

Radio \& Television. Administrative Council of the International Radio and Television Or- ganization, Prague XVI, Liebknechtova 15, Czechoslovakia. 1, February 1960. 6 nos. a year. $\$ 6$.

Radiological Health Data. U. S. Dept. of Commerce, Office of Technical Services, Washington 25, D. C. April 1960. Monthly. \$3., 6 months' subscription.

A Review of English Literature. Longmans, Green \& Company, 6 \& 7 Clifford Street, London, W1. v. 1, no. 1, January 1960. Frequency not given. $15 \mathrm{~s}$.

Revue Encyclopedique de l'Afrique. Editions Universitaires de l'Afrique, Immeuble C. I. C. A., Avenue Charles de Gaulle, Abidjan, French West Africa. no. 1, January 1960. 3.400 fr. CFA (edition complète). 2.700fr. CFA (édition simple).

Salon 13. Instituto Guatemalteco Americano, 13 Calle 2-52, zona 1, Guatemala, C. A. v. 1, no. 1, February 1960. Quarterly. \$2.

Soviet Geography: Review and Translation. American Geographical Society, Broadway at 156th Street, New York 32. v. 1, no. 1/2, January-February 1960. Monthly (except July and August). \$6.

Stanford University. Food Research Institute. Studies. Stanford, Calif. v. 1, no. 1, February 1960. 3 nos. a year. $\$ 7$.

Wisconsin Studies in Contemporary Literature. University of Wisconsin, 1118 West Johnson Street, Madison 6. v. 1, no. 1, Winter 1960 3 nos. a year. $\$ 2.50$.

\title{
Leadership in Academic Libraries
}

\author{
(Continued from page 380)
}

the professions so close that it might be taken as a matter of course that some teaching is a common preparation for a library career or the reverse. Such a flexible situation would, I think, strengthen both professions.

Let us then find leadership for our academic libraries wherever it can be located, nourish it at whatever level it begins to emerge. There is strength in an open society, either political or professional. There are weaknesses in oriental castes or medieval guilds.
When I first moved into organized library activities quite a while ago, I was impressed most favorably by the real quality of library leadership as compared with what I had seen in learned societies. I am still impressed, and I do not worry about the quality of this leadership. The constant self-examination and critical self-appraisal of libraries and library schools lead me to suspect that the quantity will not be lacking either, that the supply of leadership will keep pace with the ever-increasing demand. 